\title{
Family Medicine Hospitalists Three Years Out of Residency: Career Flexibility or a Threat to Office-Based Family Medicine?
}

\author{
Ramon S. Cancino, MD, MSc and Brian W. Jack, MD
}

\section{(J Am Board Fam Med 2018;31:677-679.)}

The 2015 and 2016 Association of American Medicinal Colleges (AAMC) Medical School Graduation Questionnaire all Schools Summary Report indicated that 18.4 and $18.9 \%$ of graduates, respectively, were interested in hospitalist medicine. ${ }^{1,2} \mathrm{~A}$ report released in June 2016 by the AAMC analyzing characteristics of the growing primary care hospitalist workforce between the years 2012 and 2013 indicated that $17.2 \%$ of hospitalists identified as family medicine physicians. ${ }^{3}$ A majority of family medicine physicians use hospitalist services, ${ }^{4}$ and hospitalists have a significant educational role in family medicine resident training. ${ }^{5}$

In this edition of the fournal of the American Board of Family Medicine, Kamerow et $\mathrm{al}^{6}$ using data from the 2016 Family Medicine National Graduate Survey found that $9 \%$ of family physicians who were 3 years out of residency training self-identified as hospitalists. These family physician hospitalists were significantly more likely than their nonhospitalist peers to be male, work longer hours, be better paid, and be more satisfied with their work. ${ }^{7}$ This finding, perhaps unsurprising, has implications for family medicine.

Recent residency graduate interest in hospitalbased practice is likely related to financial, lifestyle, and practice characteristics. From 2011 to 2015, family medicine hospitalists saw an average com-

From Department of Family \& Community Medicine, University of Texas Health Science Center at San Antonio, Joe R. \& Teresa Lozano Long School of Medicine, San Antonio, TX (RSC); Boston University School of Medicine, Boston Medical Center, Boston, MA (BWJ).

Funding: none.

Conflict of interest: none declared.

Corresponding author: Brian W. Jack, MD, Boston University School of Medicine, Boston Medical Center, Dowling 5, 1 BMC Place, Boston, MA 02118 (E-mail: Brian.jack @bmc.org). pensation increase of $4.7 \%$, bringing the average salary to $\$ 285,213$ compared with $\$ 230,456$, the average compensation for a family medicine physician who does not practice obstetrics. ${ }^{8}$ In general, hospitalists from all specialties are earlier in their careers than the average primary care physician. ${ }^{9}$ Hospitalists are more likely to agree that their work schedule leaves enough time for their personal life and family as compared with outpatient general internists. ${ }^{9}$ There is more direct integration into a consistent care team, perhaps more satisfaction of taking care of patients who are acutely ill, and, often, the opportunity to learn and apply up-todate treatments. Kruse ${ }^{10}$ showed that, along with medical school admission policy and medical school educational environment, practice environment and physician income are 4 important variables that influence career choice. Work-life integration, salary, and opportunity for further professional growth seem to be important components in this choice and reflect what a hospitalist career can offer. These issues also influence a workforce's well-being and resilience. ${ }^{11}$

More is being learned about the retention of physicians in hospitalist careers. Burnout is common among hospitalists and is related to increased likeliness to leave and reduce work effort. ${ }^{12}$ A 2015 survey reported the average hospitalist turnover rate was $6.9 \%$ per year. ${ }^{13}$ Reported burnout rates range from $12.9 \%$ to $27.2 \% .^{9}$ In a survey of 130 internal medicine hospitalists and 448 outpatient general internists, Roberts et $\mathrm{al}^{9}$ found burnout to be more common among hospitalists, although hospitalists were more satisfied with work-life balance.

Are family physicians choosing hospitalist careers because they are more satisfying? Outpatient physicians report more emotional exhaustion than 
inpatient physicians. ${ }^{14}$ According to Kamerow et $\mathrm{al}^{6}{ }^{6}$ at 3 years out of residency, $84.3 \%$ of family physicians are satisfied or very satisfied compared with family physician hospitalists who rated satisfaction as $92.3 \%$.

Family medicine-trained physicians choosing to work as hospitalists have consequences for the primary care workforce. Despite ample evidence that well-trained family physicians practicing in a community setting contribute greatly to that community's health, ${ }^{15}$ recruitment of physicians into office-based family medicine is challenging, an unfortunate reality given that recent estimates predict a shortage of 52,000 ambulatory primary care physicians by $2025 .^{16}$

Historically, family medicine was founded as a specialty whose residency programs were designed to train physicians to provide comprehensive and continuous care to families and communities. Many in family medicine believe that somehow we are failing in this mission if some percentage of our graduates do not practice office-based family medicine. Is there a risk of expanding career choice for our graduates, while decreasing primary care access nationally?

The debate about creating opportunities for family physicians to practice in areas outside of traditional primary care practice has been a previous topic of conversation, for instance, in the areas of geriatrics, sports medicine, and more recently in palliative care delivery. ${ }^{17}$ The concern is often expressed as one of delivering on the values of family medicine and providing an adequate primary care workforce for the health of the country. This dynamic has already occurred in internal medicine. For more than half a century, internal medicine has increasingly offered multiple subspecialization options for its graduates, which has now resulted in only $10 \%$ to $20 \%$ of its graduates practicing primary care. In contrast, $91 \%$ of family medicine residents are likely to practice primary care. ${ }^{18}$ Is it possible that the expanding hospitalist role within family medicine represents the beginning of the slippery slope that results in more family physicians practicing specialty care and fewer in primary care while exacerbating our national primary care need?

As in the past, family medicine training and the practice of family medicine will continue to evolve. It is possible that a reemerging role for family medicine in the hospital could strengthen the spe- cialty. Increasing the array of perceived career options for family medicine graduates could realistically increase recruitment of medical students into family medicine. Furthermore, a family medicine hospitalist may be quite a valuable a team member in the continued evolution of value-based health care delivery. Family physicians could influence the elements of hospital-based, community-based, and practice-based transitions of care programs that are shown to decrease unnecessary hospital readmis$\operatorname{sion}^{19-21}$ and improve the patient experience. ${ }^{22} \mathrm{Ul}-$ timately, the increasing number of family medicine hospitalists could be a signal of the evolving family medicine workforce, as the concept of continuity expands to nonoffice-based episodes of care, and the importance of such care continues to be demonstrated.

To see this article online, please go to: http://jabfm.org/content/ 31/5/677.full.

\section{References}

1. Association of American Medical Colleges. 2015 All Schools Summary Report. Available from: https:// www.aamc.org/download/440552/data/2015gqallschoolssummaryreport.pdf. Published 2015. Accessed June 16, 2018.

2. Association of American Medical Colleges. 2016 All Schools Summary Report. Available from: https:// www.aamc.org/download/464412/data/2016gqallschoolssummaryreport.pdf. Published 2016. Accessed June 16, 2018.

3. Jones KC, Whaley MM. Hospitalists: a growing part of the primary care workforce. AAMC Anal Brief 2016;16. Available from: https://www.aamc.org/ download/462728/data/june2016hospitalistsagrowingpartoftheprimarycareworkforce.pdf. Accessed June 17, 2018.

4. Ivins D, Blackburn B, Peterson LE, et al. A majority of family physicians use a hospitalist service when their patients require inpatient care. J Prim Care Community Health 2015;6:70-6.

5. Baldor R, Savageau JA, Shokar N, et al. Hospitalist involvement in family medicine residency training: a CERA study. Fam Med 2014;46:88-93.

6. Kamerow DB, Wingrove P, Petterson S, Peterson L, Bazemore A. Characteristics of young family physician hospitalists. J Am Board Fam Med 2018;31: 680-681.

7. Medscape Hospitalist Compensation Report 2017. Medscape. Available from: https://www.medscape. com/sites/public/physician-comp/2017. Published 2017. Accessed June 16, 2018.

8. Quinn R. The state of hospital medicine is strong. Available from: https://www.the-hospitalist.org/ hospitalist/article/121482/state-hospital-medicine- 
strong. Published September 2016. Accessed June 16, 2018.

9. Roberts DL, Shanafelt TD, Dyrbye LN, West CP. A national comparison of burnout and work-life balance among internal medicine hospitalists and outpatient general internists. J Hosp Med 2014;9: $176-81$.

10. Kruse J. Income ratio and medical student specialty choice: Fam Med 2013;45:281-3.

11. Brigham T, Barden C, Dopp AL, et al. A journey to construct an all-encompassing conceptual model of factors affecting clinician well-being and resilience. NAM Perspectives. Washington DC: National Academy of Medicine; 2018.

12. Hinami K, Whelan CT, Wolosin RJ, Miller JA Wetterneck TB. Worklife and satisfaction of hospitalists: toward flourishing careers. J Gen Intern Med 2012;27:28-36.

13. Vuong K. Turnover rate for hospitalist groups trending downward. Available from: https:// www.the-hospitalist.org/hospitalist/article/130462/ turnover-rate-hospitalist-groups-trending-downward. Published February 1, 2017. Accessed June 16, 2018.

14. Roberts DL, Cannon KJ, Wellik KE, Wu Q, Budavari AI. Burnout in inpatient-based versus outpatient-based physicians: a systematic review and metaanalysis. J Hosp Med 2013;8:653-64.
15. Starfield B, Shi L, Macinko J. Contribution of primary care to health systems and health. Milbank Q 2005;83:457-502.

16. Petterson SM, Liaw WR, Phillips RL, Rabin DL, Meyers DS, Bazemore AW. Projecting US primary care physician workforce needs: 2010-25. Ann Fam Med 2012;10:503-9.

17. Shadd J. Should palliative care be a specialty? Can Fam Physician 2008;54:840-2.

18. Iglehart JK. Health reform, primary care, and graduate medical education. N Engl J Med 2010;363: 584-90.

19. Jack BW, Chetty VK, Anthony D, et al. A reengineered hospital discharge program to decrease rehospitalization: a randomized trial. Ann Intern Med 2009; 150:178-87.

20. Coleman EA, Parry C, Chalmers S, Min S-J. The care transitions intervention: results of a randomized controlled trial. Arch Intern Med 2006;166:1822-8.

21. Naylor MD, Brooten DA, Campbell RL, Maislin G, McCauley KM, Schwartz JS. Transitional care of older adults hospitalized with heart failure: a randomized, controlled trial. J Am Geriatr Soc 2004;52:675-84.

22. Cancino RS, Manasseh C, Kwong L, Mitchell SE, Martin J, Jack BW. Project RED Impacts the Patient Experience. J Patient Exp 2017;4:185-90. 